\title{
MODELIRANJE ODREDNICA POTRAŽNJE ZA ŽIVOTNIM OSIGURANJEM U ZEMLJAMA ORGANIZACIJE ZA EKONOMSKU SURADNJU I RAZVOJ
}

\author{
MODELING THE DETERMINANTS OF DEMAND FOR \\ LIFE INSURANCE IN ORGANIZATION FOR ECONOMIC \\ COOPERATION AND DEVELOPMENT COUNTRIES
}

SAŽETAK: Republika Hrvatska je 2017. formalno aplicirala za članstvo u Organizaciji za ekonomsku suradnju i razvoj (OECD), organizaciji koja kao jednu od glavnih smjernica zemljama pristupnicama ističe značaj životnog osiguranja za razvoj financijskog tržišta. Realnost na hrvatskom financijskom tržištu, izražena je bankocentričnost te nizak i stagnirajući razvoj životnog osiguranja. U svrhu identifikacije ključnih čimbenika razvoja tržišta životnog osiguranja, članak istražuje odrednice potražnje za životnim osiguranjem zemalja OECD-a u razdoblju od 2008. do 2018. godine, odnosno u razdoblju tijekom i nakon globalne ekonomske i financijske krize. Uzimajući u obzir utjecaj krize, kao i procese starenja stanovništva, kao moguće odrednice analizirani su različiti ekonomski, demografski i socijalni čimbenici. U empirijskoj analizi korišten je dinamički panel model, pri čemu je primijenjen Arellano-Bover / Blundell-Bond sistemski procjenitelj koji se smatra prikladnijim u slučajevima kada broj analiziranih razdoblja nije velik.

KLJUČNE RIJEČI: životno osiguranje, OECD, potražnja za životnim osiguranjem, dinamički panel model

ABSTRACT: In 2017 Croatia presented a formal application for accession to the Organisation for Economic Co-operation and Development (OECD), an economic organisation that, amongst the main guidelines for the accession countries, highlights the importance of life insurance for the development of the financial market. On the other hand, the reality of the Croatian financial market is a highly bank-centric financial system and a low and stagnating share of life insurance. To identify the main factors of the development of the market for life insurance, the article investigates determinants of demand for life insur- 
ance of OECD countries in the period from 2008 to 2018, i.e. the period the period during and after the 2008 global financial and economic crisis. Considering the crisis effects as well as population aging, the paper investigates different economic, demographic and social factors as possible determinants. The dynamic panel model is applied in the empirical analysis.Arellano-Bover/Blundell-Bond system estimator was applied, which is considered to be an appropriate estimator in cases when the analysed period is relatively short.

KEYWORDS: life insurance, OECD, demand for life insurance, dynamic panel model

\section{UVOD}

U uvjetima sve intenzivnije globalizacije pristupanje ekonomskim integracijama i sklapanje trgovinskih sporazuma osnovni su preduvjeti poboljšanja trgovinske razmjene i posljedično ekonomske aktivnosti i standarda građana. Osim ekonomskih integracija postoje i brojne međunarodne ekonomske organizacije među kojima je najznačajnija Organizacija za ekonomsku suradnju i razvoj (engl. Organisation for Economic Cooperation and Development - OECD), osnovana 1961. godine s ciljem poboljšanja blagostanja. Pritom, OECD naglasak stavlja na primjenu adekvatnih ekonomskih politika i jačanje tržišnog gospodarstva i međunarodne razmjene.

Za razliku od ekonomskih integracija koje nose konkretne koristi, kao što su slobodno kretanje robe i pristup određenom tržištu, kao i mogućnost korištenja određenih fondova, koristi od članstva u OECD-u nisu mjerljive u tom smislu. Zapravo, članstvo u OECD-u je svojevrstan indikator investitorima da zemlja ima uspostavljenu tržišnu ekonomiju i da je dosegla određenu razinu ekonomskog razvoja, u smislu standarda građana, kao i razvoja financijskih tržišta. Nadalje, za razliku od ekonomskih integracija, odluke OECD-a nisu obvezujućeg karaktera.

Premda su intencije Republike Hrvatske (RH) za dobivanjem članstva u OECD-u neformalno iskazane neposredno nakon osamostaljenja, tek je 2017. godine formalno predan zahtjev za članstvom u OECD-u. U međuvremenu RH sudjeluje u OECD-ovim programima za zemlje jugoistočne Europe. Primjerice, SIGMA program za poboljšanje državnih institucija i istraživanja procjena znanja i vještina petnaestogodišnjih učenika (engl. Programme for International Student Assessment - PISA). U okviru svojih programa, jedna od važnijih smjernica OECD-a zemljama u razvoju jest isticanje važnosti životnog osiguranja za zemlje u razvoju i to s više aspekata (OECD, 2004. - Developing life insurance in the economies in transition):

- S aspekta pojedinca, predstavlja oblik štednje, pruža sigurnost pojedincu u slučaju nastupa bolesti, smrti i starosti.

- S aspekta državnog proračuna, ublažava teret financiranja socijalnih izdataka.

- S aspekta ekonomije, unapređuje ekonomski razvoj kroz jačanje kapaciteta osiguravajućih društava kao institucionalnih investitora na financijskom tržištu.

Vodeći računa o izraženoj bankocentričnosti financijskog tržišta RH, zanimljivo je promotriti koje su odrednice potražnje za životnim osiguranjem u zemljama članicama OE$\mathrm{CD}$-a s diverzificiranijim financijskim tržištima. Prethodna istraživanja odrednica potra- 
žnje za životnim osiguranjem u zemljama OECD-a su većinom starijeg datuma i mahom se odnose na razdoblje prije globalne ekonomske i financijske krize 2008. godine. Stoga je cilj provedene empirijske analize istraživanje odrednica potražnje za životnim osiguranjem u zemljama OECD-a, pri čemu istraživanje uključuje razdoblje krize 2008. godine, kao i razdoblje oporavka. Na taj način provedeno istraživanje omogućuje uvid u eventualne promjene u odrednicama potražnje, koje su uslijedile nakon krize, i doprinosi boljem razumijevanju odrednica potražnje za zemlje s razvijenijim financijskim tržištima.

Primijenjen je dinamički panel model kao prikladan način modeliranja dinamike svojstvene brojnim ekonomskim odnosima, tako i potražnji za životnim osiguranjem. Dinamički panel model za analizu potražnje za životnim osiguranjem primijenili su i Li et al. (2007). Međutim, za razliku od sistemskog procjenitelja generaliziranom metodom momenata (engl. Generalized Method of Moments - GMM) primijenjenog u Li et al. (2007), u ovom članku je primijenjen Arellano-Bover / Blundell-Bond sistemski procjenitelj koji se smatra prikladnijim kada broj analiziranih vremenskih razdoblja nije velik (Arellano i Bover, 1995; Blundell i Bond, 1998). Sukladno tome, primjena navedenog procjenitelja trebala bi omogućiti bolje sagledavanje eventualnih promjena u odrednicama potražnje za životnim osiguranjem u zemljama OECD-a u razdoblju nakon krize.

Provođenjem empirijske analize bit će istražene sljedeće hipoteze:

- Poboljšanje indikatora ekonomske razvijenosti povećava potražnje za životnim osiguranjem u zemljama OECD-a.

- Porast inflacije kao indikatora monetarne nesigurnosti, negativno utječe na potražnju za životnim osiguranjem u zemljama OECD-a.

- Porast udjela gradskog stanovništva u ukupnom dovodi do veće potražnje za životnim osiguranjem u zemljama OECD-a.

Navedene su hipoteze u skladu s rezultatima prethodnih istraživanja. Međutim, za dio odrednica potražnje za životnim osiguranjem u zemljama OECD-a postoji mogućnost da se rezultati ne podudaraju s dosadašnjim prevladavajućim zaključcima. Naime, uslijed procesa starenja stanovništva s kojim je većina zemalja OECD-a suočena, postoji mogućnost da je zbog sve manjeg relativnog udjela radnog kontingenta u ukupnom stanovništvu (dijela stanovništva koji čini najveći udio kupaca polica životnog osiguranja) došlo do određenih promjena u utjecaju demografskih čimbenika. Konkretno:

- Povećanje broja uključenih u obrazovni sustav dovodi do smanjenja radne snage i u konačnici negativno utječe na potražnju za životnim osiguranjem u zemljama OECD-a.

- Porast očekivanog životnog vijeka dovodi do smanjenja potražnje za životnim osiguranjem u zemljama OECD-a.

- Povećanje omjera zavisnosti mladih (udio stanovništva mlađeg od 15 godina u radno sposobnom stanovništvu) dovodi do smanjenja potražnje za životnim osiguranjem u zemljama OECD-a.

Također, u empirijskoj analizi, razmotren je i utjecaj globalne ekonomske i financijske krize 2008. godine. S obzirom na to da životna osiguranja imaju izražen dugoročni aspekt, očekuje se da kriza neće imati statistički značaj na potražnju za životnim osiguranjem u zemljama OECD-a. 
Članak se sastoji od šest dijelova. Poslije uvodnog dijela dan je pregled literature o čimbenicima potražnje za životnim osiguranjem. Slijedi opis podataka i korištene metodologije, nakon kojeg su prikazane osnovne karakteristike tržišta životnih osiguranja zemalja OECD-a, te rezultati provedene empirijske analize i zaključak.

\section{PREGLED LITERATURE}

Uloga životnog osiguranja na tržištu kapitala sve je veća. Paralelno sa sve većim značajem životnog osiguranja, raste i broj istraživanja o najznačajnijim čimbenicima potražnje za životnim osiguranjem. Na temelju teorijskog okvira koji je omogućio istraživanje odrednica potražnje za životnim osiguranjem (Yaari, 1965; Hakansson, 1969) proveden je niz istraživanja. Prvotno su se istraživanja provodila za pojedinačne zemlje. Međutim, razvojem panel modela, sve se više provode istraživanja za skupine zemalja, koristeći prednosti primjene panel metodologije nad analizom zasebnih modela pojedinačnih zemalja ili združenog OLS (engl. Ordinary Least Squares) modela.

Među prvim istraživanjima odrednica potražnje za životnim osiguranjem za skupinu zemalja korištenjem panel metodologije izdvaja se članak Beck i Webb (2003). Istraživanje je provedeno za 68 zemalja i uključuje zemlje sa svih kontinenata te različitih stupnjeva ekonomskog razvoja, a korišteni su statički panel modeli. Poput članka Beck i Webb (2003) postoje i druga istraživanja koja uključuju zemlje različitog stupnja razvoja, kao što su Browne i Kim (1993) koji primjenjuju združeni OLS model. Ipak, najveći je broj istraživanja proveden za zemlje OECD-a ili zemlje određene ekonomske integracije (poput EU-a, azijske ekonomske integracije...). Većinom je riječ o razvijenim ekonomijama s uspostavljenim tržišnim ekonomijama i razvijenim financijskim tržištima. Li et al. (2007) u istraživanju provedenom za zemlje OECD-a primjenjuju dinamički panel model. Konkretno, koriste GMM procjenitelj kako bi anulirali problem heteroskedastičnosti koju su uočili kao glavni razlog proturječnih rezultata u prijašnjim istraživanjima odrednica potražnje za životnim osiguranjem. GMM procjenitelj koriste i Ćurak et al. (2019) u istraživanju provedenom za 129 zemalja različitog stupnja razvoja.

Bitno je istaknuti kako zanimljiva saznanja nude i istraživanja provedena za zemlje u razvoju. Primjerice, Zerriaa i Noubbigh (2016) za zemlje Bliskog Istoka i Sjeverne Afrike, Outreville (1996) na uzorku od 90 zemalja u razvoju, Kjosevski (2012), Elango i Jones (2011) i Ćurak i Kljaković-Gašpić (2011) za zemlje srednje, istočne i jugoistočne Europe te Anđelinović et al. (2016) za nove zemlje članice Europske unije. Rezultati spomenutih istraživanja između ostalog ukazuju i na velik značaj kulturoloških specifičnosti zemalja.

Istraživanja odrednica potražnje za životnim osiguranjem koriste slične varijable koje je moguće podijeliti u nekoliko skupina. Prema tome, među najznačajnijim čimbenicima potražnje za životnim osiguranjem razlikuju se: 1) ekonomski, 2) demografski i socijalni te 3) institucionalni čimbenici.

Od ekonomskih čimbenika u empirijskim istraživanjima (Kjosevski, 2012; Browne i Kim, 1993, Beck i Webb, 2003; Outreville, 1996) najčešće su korišteni indikatori ekonomske razvijenosti (poput dohotka po glavi stanovnika), neizvjesnost (poput inflacije), prinos na uložena novčana sredstva (primjerice realna kamatna stopa) i razina razvoja financijskog sustava (mjerena udjelom monetarnih agregata ili kredita/imovine poslovnih banaka u BDP-u). 
Od demografskih i socijalnih čimbenika u primijenjenim istraživanjima najčešće se koriste indikatori obrazovanja, urbanizacija, udio mladih odnosno starih osoba u radno aktivnom stanovništvu, očekivani životni vijek, religija i sustav socijalne skrbi. Između ostalih, demografske i socijalne čimbenike istraživali su Truett i Truett (1990), Browne i Kim (1993), Outreville (1996), Li et al. (2007) i Ward i Zurbruegg (2000).

Kao reprezentant institucionalnih čimbenika u literaturi se najčešće koriste varijable koje odražavaju političku stabilnost zemlje, mogućnost suzbijanja i preveniranja korupcije, kao i indikatori razine vladavine prava u zemlji. Bitno je istaknuti da su institucionalne odrednice važnije u kontekstu tranzicijskih ekonomija. S obzirom na to da su članice OE$\mathrm{CD}$-a većinom zemlje s uspostavljenom tržišnom ekonomijom i razvijenom institucionalnom infrastrukturom, u ovom članku se institucionalni čimbenici neće razmatrati.

Prema tome, prethodna istraživanja su osim zemalja OECD-a uključivala i ostale zemlje različitih stupnjeva razvoja. Međutim, istraživanja koja su se bavila isključivo zemljama OECD-a su većinom starijeg datuma i mahom se odnose na razdoblje prije globalne ekonomske i financijske krize 2008. godine. Stoga, ovaj članak istražuje učinak krize na potražnju za životnim osiguranjem u zemljama OECD-a, ali i prilagodbe koje su uslijedile nakon krize. Nadalje, u članku se razmatra i mogući utjecaji starenja stanovništva koje poprima sve veće razmjere u razvijenim ekonomijama, pri čemu prednjače europske zemlje članice OECD-a.

\section{PODACI I METODOLOGIJA}

Sukladno raspoloživosti podataka, empirijska analiza provedena je za razdoblje od 2008. do 2018. godine $(T=11)$. Nadalje, u analizu su uključene sve zemlje OECD-a osim Novog Zelanda za koji nisu dostupni podaci o potražnji za životnim osiguranjem. Prema tome, riječ je o 36 od ukupno 37 zemalja članica $(N=36)$ : Australija, Austrija, Belgija, Kanada, Čile, Kolumbija, Češka, Danska, Estonija, Finska, Francuska, Njemačka, Grčka, Mađarska, Island, Irska, Izrael, Italija, Japan, Južna Koreja, Latvija, Litva, Luksemburg, Meksiko, Nizozemska, Norveška, Poljska, Portugal, Slovačka, Slovenija, Španjolska, Švedska, Švicarska, Turska, UK i SAD.

Zavisna varijabla korištena u empirijskoj analizi jest potražnja za životnim osiguranjem u zemljama OECD-a (INS) mjerena kao udio premije životnog osiguranja u BDP-u. Nezavisne varijable, odnosno reprezentanti odrednica potražnje za životnim osiguranjem u zemljama OECD-a odabrane su u skladu s prethodnim istraživanjima iz skupina ekonomskih te demografskih i socijalnih čimbenika.

Jedan od najvažnijih ekonomskih čimbenika je dohodak, za koji se smatra da pozitivno utječe na potražnju za proizvodima životnih osiguranja, jer porastom razine dohotka dolazi i do rasta potražnje za životnim osiguranjem (Kjosevski, 2012; Browne i Kim, 1993; Beck i Webb, 2003; Outreville, 1996). Navedena istraživanja kao razlog povećane potražnje navode povećanu potrošnju koja raste s dohotkom upravo radi zaštite potencijalnog dohotka osiguranika i očekivane potrošnje njegovih uzdržavanih članova. S obzirom na to da veći dohodak omogućava i potrošnju izvan okvira primarnih potreba, osiguranje se smatra i luksuznim dobrom. Također, gledajući na globalnoj razini, konkurentno gospodarstvo potiče rast i ostalih gospodarskih sektora, ne samo sektora osiguranja (Anđelinović et al., 2016). 
Kao reprezentant nacionalnog dohotka u većini istraživanja, pa tako i ovom, korišten je BDP po stanovniku, koji pokazuje pozitivan utjecaj na potražnju za životnim osiguranjem. Sukladno navedenome, varijabla dohodak (GDP) mjerena je kao BDP po stanovniku (u konstantnim cijenama, bazna godina je 2015) i u literaturi se pretpostavlja da pozitivno utječe na potražnju za životnim osiguranjem.

Nadalje, od ekonomskih čimbenika korištena je i stopa inflacije, mjerena pomoću indeksa potrošačkih cijena. Inflacija se koristi za objašnjavanje novčane discipline određene zemlje. Budući da su proizvodi životnog osiguranja štedno-ulagačkog karaktera koji donosi dugoročnu korist štedišama, vrlo je lako zaključiti da će porast inflacije koja umanjuje vrijednost novca u budućnosti, obeshrabriti ljude od štednje. S obzirom na navedeno, neupitna je pojava monetarne nesigurnosti koja negativno utječe na potražnju za životnim osiguranjem (Kjosevski, 2012). Većina istraživanja, dokazala su značajan i negativan utjecaj inflacije na osigurateljnu potrošnju, poput Ward i Zurbruegg (2000) koji su u svom istraživanju pokazali kako inflacija ima značajniji utjecaj u azijskim zemljama nego u zemljama OECD-a. Uz navedena, postoje i istraživanja koja su došla do zaključka da porast stope inflacije povećava potražnju za životnim osiguranje. Jedno od njih je istraživanje Zerriaae i Noubbigha (2016), provedeno na uzorku zemalja Bliskog istoka i Sjeverne Afrike, koje je ukazalo da porast stope inflacije dovodi do povećanja potražnje za proizvodima životnog osiguranja (Anđelinović et al., 2016). U ovom istraživanju, varijabla inflacija (INFL) mjerena je pomoću indeksa potrošačkih cijena (bazna godina 2015) i, u većini istraživanja, pretpostavlja se negativna veza između inflacije i potražnje za životnim osiguranjem.

Od demografskih i socijalnih čimbenika u primijenjenim se istraživanjima najčešće koriste indikatori obrazovanja, urbanizacija, udio mladih odnosno starih osoba u radno aktivnom stanovništvu, očekivani životni vijek, religija i sustav socijalne skrbi.

S obzirom na prethodna istraživanja poput onih koja su proveli Truett i Truett (1990), Browne i Kim (1993), te Outreville (1996), razina obrazovanja bi trebala imati pozitivan utjecaj na potražnju za životnim osiguranjem. Kao reprezentant obrazovanja koristi se aritmetička sredina indeksa očekivanog trajanja obrazovanja i indeksa prosječnih godina školovanja. Truett i Truett (1990) u svom istraživanju naglašavaju povezanost više razine obrazovanja s jačom željom da se zaštiti i poveća životni standard uzdržavanih osoba, dok Browne i Kim (1993) te Outreville (1996) tumače kako je razina obrazovanja pozitivno povezana s averzijom prema riziku pa se tako povećava i potražnja za različitim vrstama osiguranja. Također, istraživanje koje su proveli Li et al. (2007) naglašava da s rastom prosječnih godina školovanja dolazi do veće ovisnosti uzdržavanih osoba te posljedično i do veće potražnje za životnim osiguranjima, upravo kako bi se zaštitile uzdržavane osobe. Konačno, bitno je istaknuti da povećanje broja ljudi uključenih u obrazovni sustav dovodi do smanjenja radne snage, pa posljedično i do smanjenja ukupnog BDP-a zemlje, što ukazuje na dvosmislen utjecaj obrazovanja na potražnju za životnim osiguranjem. U ovom istraživanju, obrazovanje (EDU) je definirano kao aritmetička sredina indeksa očekivanog trajanja obrazovanja i indeksa prosječnih godina školovanja.

Očekivani životni vijek, mjeren kao očekivani broj godina pri rođenju, prema brojnim je istraživanjima u pozitivnoj korelaciji s potražnjom za životnim osiguranjem. Pozitivan utjecaj na rast potražnje potvrdili su Ward i Zurbruegg (2000) te Browne i Kim (1993) Osim toga, novim društvima za osiguranje će zemlje u kojima je vidljiv porast očekivanog životnog vijeka, biti atraktivnije, s obzirom na to da je to jedan od pokazatelja poboljšanja 
životnih uvjeta. Također, iz razloga što je očekivani životni vijek u korelaciji s dohotkom i nacionalnim bogatstvom, ne može se jednoznačno zaključiti da će porast očekivanog životnog vijeka dovesti do porasta potražnje za životnim osiguranjem (Anđelinović et al., 2016). Upravo su do suprotnog zaključka došli Li et al. (2007) koji su na primjeru zemalja OECD-a dokazali negativan odnos očekivanog životnog vijeka i potražnje za životnim osiguranjem. U ovom članku, očekivani životni vijek (EXP) mjeren je kao očekivani broj godina života pri rođenju.

Kada se govori o urbanizaciji, odnosno o udjelu gradskog stanovništva u ukupnom, može se pretpostaviti da će gospodarstva s većom urbanizacijom imati veću potražnju za životnim osiguranjem. Brojna su istraživanja, pa tako i ono koje su proveli Beck i Webb (2003), otkrila da postoji pozitivna veza između potražnje za životnim osiguranjem i urbanizacijom. Uz to, naglašavaju i manje oslanjanje na neformalne ugovore o osiguranju, što može dovesti do povećanja za formalnim proizvodima osiguranja. Također, u svom istraživanju Hwang i Gao (2003) iznose kako rast urbanog stanovništva predstavlja jednu od najvažnijih promjena u kineskoj socijalnoj strukturi. Ukazali su na trend odlaska mladih iz tradicionalnih obitelji u gradove, što rezultira manjom ovisnošću o roditeljima, želji za financijskom slobodom te naposljetku i potražnji za proizvodima životnog osiguranja. Nadalje, omogućena je i jednostavnija distribucija proizvoda životnih osiguranja koja prodajnim predstavnicima smanjuje troškove povezane s preuzimanjem ugovora, marketingom, naplatom premija i rješavanjem šteta (Beck i Webb, 2003). Usprkos očitom pozitivnom utjecaju urbanizacije na potražnju za životnim osiguranjem, empirijskim istraživanjima ukazuje se na dvosmislen utjecaj urbanizacije na potražnju za životnim osiguranjem. U ovom istraživanju, urbanizacija (URBAN) predstavlja udio gradskog u ukupnom stanovništvu.

Omjer zavisnosti mladih izražen je kao udio stanovništva mlađeg od 15 godina u radno sposobnom stanovništvu (od 15 do 64 godine). S obzirom na pretpostavku da povećanje zavisnosti mladih o radnoj populaciji povećava potražnju za zaštitom od rizika smrti i smanjuje potražnju za štednjom, u istraživanju koje su proveli Beck i Webb (2003) vidljivo je da je omjer zavisnosti mladih u dvosmislenoj korelaciji sa životnim osiguranjem. Upravo zbog toga, oni ne pronalaze važnost utjecaja broja uzdržavanih osoba na potražnju za životnim osiguranjem. Ipak, postoje i istraživanja poput onih koja su proveli Beenstock et al. (1986), Browne i Kim (1993) te Truett i Truett (1990) koja ukazuju na pozitivan učinak omjera zavisnosti mladih na potražnju za životnim osiguranjem. Omjer zavisnosti mladih (YOUNG) izražen je kao udio stanovništva mlađeg od 15 godina u radno sposobnom stanovništvu (od 15 do 64 godine).

Podaci za varijable INS, GDP, INFL, i EXP prikupljeni su iz baze podataka OECD-a. Podaci za varijablu EDU segment su ljudskog razvojnog indeksa (engl. Human Development Index - HDI) Ujedinjenih naroda (UN). Za varijable URBAN i YOUNG izvor je Svjetska banka.

Nadalje, s obzirom na to da je početkom promatranog razdoblja na analizirane indikatore potencijalno utjecala globalna financijska i ekonomska kriza 2008. godine, dodana je i binarna varijabla KRIZA koja poprima vrijednosti $1 \mathrm{u}$ razdoblju krize, odnosno $0 \mathrm{u}$ ostalim razdobljima.

S obzirom na to da su analizirani panel podaci, procijenjeni su odgovarajući statički panel modeli: panel model s fiksnim učincima (engl. fixed effects - FE) i panel model sa slučajnim učincima (engl. random effects - RE) (Jakšić et al, 2020). Naime, kod združenog 
OLS modela, svi analizirani podaci se jednostavno 'združe' i procjenjuje se jedan jedinstveni regresijski model metodom najmanjih kvadrata.

$$
y_{i t}=\alpha+\beta X_{i t}+\varepsilon_{i t}, i=1, \ldots, N ; t=1, \ldots, T
$$

Indeks $i$ označava zemlju, a $t$ označava vremensko razdoblje (godinu). $y_{i t}$ je zavisna varijabla (potražnja za životnim osiguranjem). $x_{i t}$ je matrica nezavisnih varijabli, a $\varepsilon_{i t}$ je greška relacije za koju se pretpostavlja da je nezavisna i identično distribuirana, tj. $\varepsilon_{i t} \sim I I D\left(0, \sigma_{\varepsilon}^{2}\right)$.

Analiza pomoću združenog OLS modela u pravilu je neprikladna iz više razloga, a prvenstveno zbog toga što se združivanjem podataka ustvari neizravno pretpostavlja kako su aritmetičke sredine varijabli i odnosi među njima konstantni u razdoblju promatranja i za sve analizirane zemlje. Kako bi se istražila neprikladnost primjene združenog OLS modela bit će provedena dva statistička testa. Kako bi se ispitalo postojanje fiksnih učinaka provodi se Chowov test. U slučaju neodbacivanja nulte hipoteze Chowova testa, zaključuje se da ne postoji neopažena heterogenost, odnosno prikladan je združeni OLS model. Nadalje, kako bi se istražilo postojanje slučajnih učinaka, provodi se Breusch-Paganov LM test. U slučaju da se nulta hipoteza Breusch-Paganova LM testa ne može odbaciti zaključuje se kako ne postoji neopažena heterogenost, odnosno prikladan je združeni OLS model.

Brojne su prednosti primjene analize modela panel podataka. Osnovni razlog za primjenu metoda za panel podatke jest mogućnost da se na taj način kontrolira neopažena heterogenost (engl. unobserved heterogeneity), odnosno čimbenici koji su specifični za pojedinu zemlju, a koje nije moguće mjeriti. Nadalje, moguće je analizirati kako se varijable ili odnosi među varijablama mijenjaju kroz vrijeme, što bi inače zahtijevalo duge vremenske nizove. Međutim, kombiniranjem prostorne i vremenske dimenzije moguće je povećati stupnjeve slobode i snagu testova korištenjem informacija o dinamici velikog broja prostornih jedinica u istom vremenskom razdoblju.

Panel model s fiksnim učincima može se zapisati kao:

$$
y_{i t}=\alpha+\beta X_{i t}+{ }_{i}+\varepsilon_{i t}, i=1, \ldots, N ; t=1, \ldots, T
$$

Indeks $i$ označava zemlju, a $t$ označava vremensko razdoblje (godinu). $y_{i t}$ je zavisna varijabla (potražnja za životnim osiguranjem). $X_{i t}$ je matrica nezavisnih varijabli. $\mu_{i}$ je individualan (fiksni) učinak za pojedinu zemlju, a $\varepsilon_{i t}$ je greška relacije za koju se pretpostavlja da je nezavisna i identično distribuirana, tj. $\varepsilon_{i t} \sim \operatorname{IID}\left(0, \sigma_{\varepsilon}^{2}\right)$.

Panel model s fiksnim učincima dan je u izrazu (3):

$$
y_{i t}=\alpha+\beta X_{i t}+\epsilon_{i}+\varepsilon_{i t}, i=1, \ldots, N ; t=1, \ldots, T
$$

Indeks $i$ označava zemlju, a $t$ označava vremensko razdoblje (godinu). $y_{i t}$ je zavisna varijabla (potražnja za životnim osiguranjem). $X_{i t}$ je matrica nezavisnih varijabli. $\epsilon_{i}$ je (slučajni) specifični učinak za pojedinu zemlju, a $\varepsilon_{i t}$ je greška relacije za koju se pretpostavlja da je nezavisna i identično distribuirana, tj. $\varepsilon_{i t} \sim \operatorname{IID}\left(0, \sigma_{\varepsilon}^{2}\right)$.

Također, dodan je i pomak zavisne varijable $y_{i t-1}$ te je procijenjen dinamički panel model (Alvarez i Arellano, 2003; Baltagi, 2013):

$$
y_{i t}=\alpha_{i}+\beta X_{i t}+\gamma \cdot y_{i t-1}+\varepsilon_{i t}, i=1, \ldots, N ; t=1, \ldots, T .
$$


Parametri dinamičkog panel modela (4) procijenjeni su primjenom Arellano-Bover (Arellano i Bover, 1995) i Blundell-Bond (Blundell i Bond, 1998) procjenitelja s robusnim standardnim pogreškama.

\section{TRŽIŠTE ŽIVOTNOG OSIGURANJA U ZEMLJAMA ORGANIZACIJE ZA EKONOMSKU SURADNJU I RAZVOJ}

U ovom poglavlju analizirani su pokazatelji koji daju uvid u razvijenost industrije osiguranja, koja je jedna od ključnih komponenti razvoja gotovo svakog gospodarstva. U tu svrhu analizirani su kretanje i struktura ukupne bruto premije, gustoća osiguranja i penetracija osiguranja u razdoblju od 2008. do 2018. godine.

Grafikon 1. Zaračunate bruto premije osiguranja u OECD-u (2008. - 2018.) u mlrd. US\$

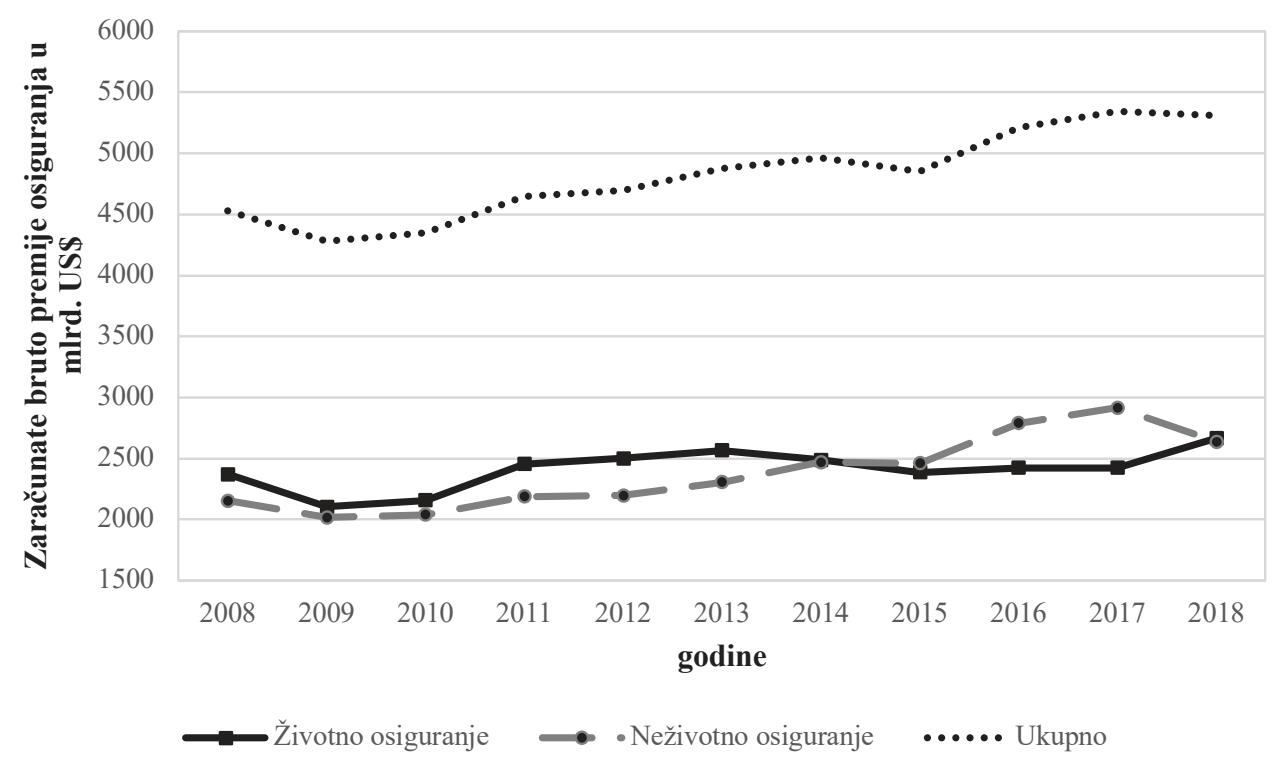

Izvor: OECD, https://stats.oecd.org

Na grafikonu 1 prikazano je kretanje zaračunatih bruto premija osiguranja u milijardama dolara za sve zemlje OECD-a, gdje se vidi kretanje premije za poslove životnog i neživotnog osiguranja te ukupno zaračunate bruto premije osiguranja, u razdoblju od 2008. do 2018. godine. Nakon očekivanog pada ukupne bruto premije sa 2008. na 2009. godinu, kada je iznosila 4.275,8 milijardi dolara, dolazi razdoblje rasta premija za životna i neživotna osiguranja, sve do 2014. godine. Ukupna bruto premija 2014. godine iznosila je 4.960 milijardi dolara, od čega na premiju životnog osiguranja odlazi 2.490,7 milijardi dolara, odnosno 50,2 \%. U tom su trenutku premije gotovo izjednačene. Od 2014. do 2017. godine vidljiv je rast bruto premija neživotnih osiguranja te blagi pad premija životnog osiguranja. 
U 2017. godini su ukupne premije osiguranja najveće i iznosile su 5.344,7 milijardi dolara, te je najveća razlika između iznosa premija životnog i neživotnog osiguranja kada od ukupnog iznosa premija osiguranja 45,37 \% odlazi na premiju životnog, dok 54,63\% odlazi na premiju neživotnog osiguranja. U 2018. godini se iznosi bruto premije životnog i neživotnog osiguranja ponovno približavaju jedan drugom, a ukupan iznos bruto premija životnih osiguranja iznosio je 2.669,3 milijardi dolara.

Grafikon 2. Struktura zaračunate bruto premije osiguranja u OECD-u (2008. - 2018.)

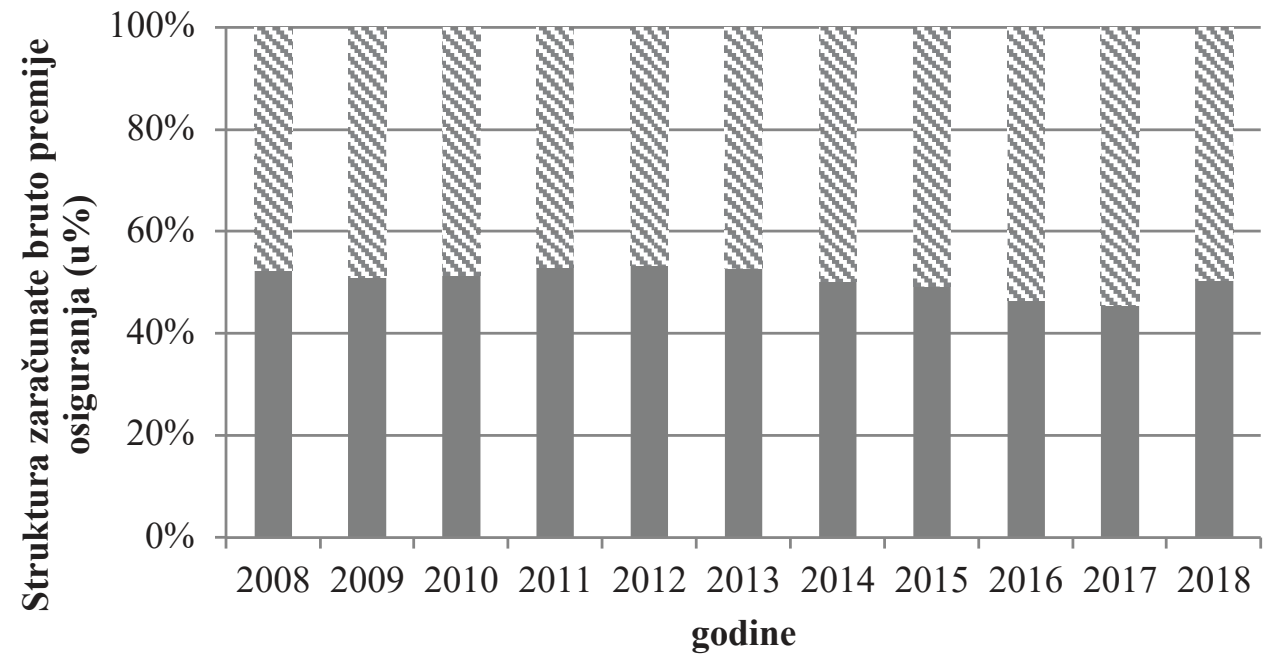

- Životno osiguranje Neživotno osiguranje

Izvor: OECD, https://stats.oecd.org

Prema grafikonu 2, a na tragu gore navedenoga u objašnjenju grafikona 1, udio premije životnih osiguranja u ukupnim bruto premijama bio je veći od udjela neživotnih osiguranja u gotovo svim godinama, osim u razdoblju od 2015. do 2017. godine. U navedenom razdoblju, udio neživotnih osiguranja prvi je put veći od udjela životnih osiguranja u ukupnim bruto premijama, a ovaj se trend nastavlja sve do 2017. godine. Isto tako, najniži udio bruto premije životnih osiguranja u ukupnoj premiji ostvaren je 2017. godine, kada je iznosio $45,38 \%$ od ukupne bruto premije, dok je najviši bio 2012. godine, kada je iznosio 53,24 \% od ukupne bruto premije osiguranja.

Gustoća životnog osiguranja, definirana kao iznos ukupne bruto premije životnog osiguranja po stanovniku, pokazuje koliko stanovnici jedne zemlje, u prosjeku, ulažu u životna osiguranja (Beck i Webb, 2002). 
Grafikon 3. Ukupna gustoća osiguranja u OECD-u (2008. - 2018.) u US\$

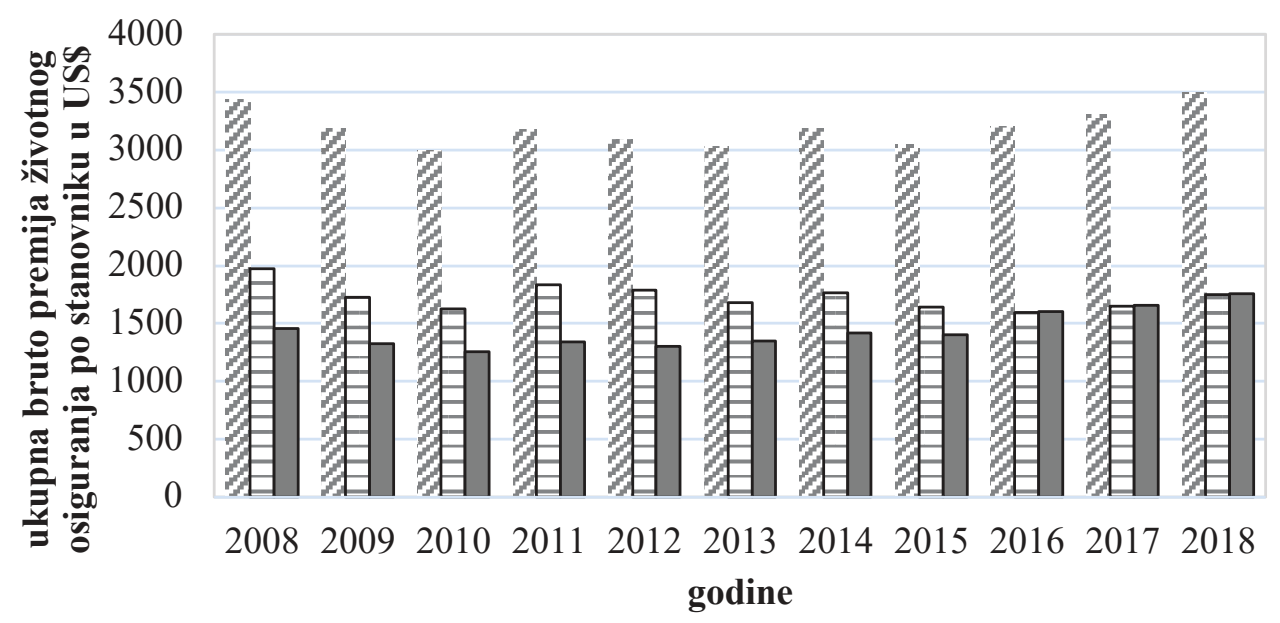

Ukupna gustoća osiguranja

๑Gustoća životnih osiguranja

$\square$ Gustoća neživotnih osiguranja

Izvor: OECD, https://stats.oecd.org

Grafikon 3 prikazuje kretanje bruto premije životnih osiguranja po stanovniku za cijelo promatrano razdoblje. U gotovo svim godinama, točnije do 2016. godine, ukupna gustoća životnih osiguranja bila je veća od gustoće neživotnih osiguranja. U tom trenutku, gustoća neživotnih osiguranja iznosi 1.601 dolar, dok je gustoća životnih osiguranja manja i iznosi 1.596 dolara. Do kraja promatranog razdoblja razlika u gustoći između životnih i neživotnih osiguranja se smanjuje, što ukazuje na porast važnosti potražnje za neživotnim osiguranjima.

Ukupna je gustoća osiguranja na početku promatranog razdoblja iznosila 3.436 dolara, dok na kraju iznosi 3.501 dolara. Upravo je u 2008. godini gustoća životnih osiguranja bila najviša i iznosila je 1.976 dolara, dok je 2015. godine bila najniža i iznosila je 1.596 dolara.

Penetracija osiguranja, definirana kao omjer zaračunate bruto premije i bruto domaćeg proizvoda (Beck i Webb, 2002), mjeri aktivnost osiguranja u odnosu na veličinu gospodarstva. 
Grafikon 4. Ukupna penetracija osiguranja u OECD-u (2008. - 2018.) u \%

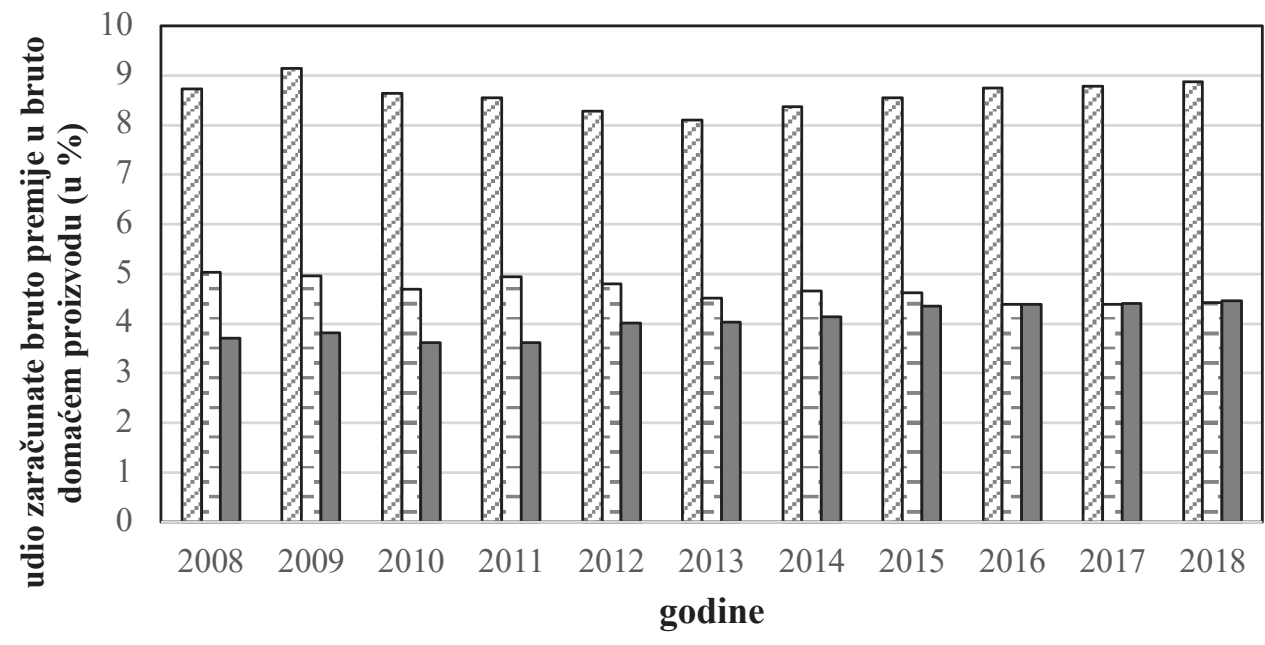

๑Penetracija ukupno $\square$ Penetracija životno $\square$ Penetracija neživotno

Izvor: OECD, https://stats.oecd.org

Grafikon 4 prikazuje kretanje ukupne penetracije osiguranja za cijelo promatrano razdoblje. Ukupna je penetracija 2008. godine iznosila $8,7 \%$, od čega je na penetraciju životnih osiguranja odlazilo 5,03\%, dok je na kraju promatranog razdoblja penetracija životnih osiguranja iznosila 4,4 \%, od ukupnih 8,9\%. Postotak od 5,03\%, koji odlazi na penetraciju životnih osiguranja u početnom razdoblju, označava njezinu najvišu vrijednost, dok postotak od 4,39 \% iz 2016. godine, označava najnižu vrijednost penetracije životnih osiguranja.

Poput gustoće, penetracija životnih osiguranja je do 2016. godine bila veća od penetracije neživotnih osiguranja. U toj se godini njihove vrijednosti gotovo izjednačavaju, kada penetracija neživotnih osiguranja iznosi 4,382 \%, dok penetracija životnih osiguranja iznosi $4,386 \%$.

\section{REZULTATI}

Rezultati empirijske analize dobiveni su na temelju podataka za 36 zemalja OECD-a, za razdoblje od 2008. do 2018. godine. Procijenjeni su združeni OLS model, izraz (1), dva statička panel modela (panel model s fiksnim učincima (FE), izraz (2) i panel model sa slučajnim učincima (RE), izraz (3) i dinamički panel model, izraz (4). Rezultati procijenjenih modela, zajedno s pripadnom dijagnostikom dani su u tablici 1. Stacionarnost nije ispitana zbog relativno kratke dužine vremenskog niza (Blackburne i Frank, 2007). Nadalje, kako su Li et al. (2007) detektirali heteroskedastičnost kao glavni razlog proturječnih rezultata u prijašnjim istraživanjima odrednica potražnje za životnim osiguranjem, ispitano je i postojanje problema heteroskedastičnosti. Kako rezultati provedenog Breusch-Paganova LM 
testa ukazuju na postojanje problema heteroskedastičnosti, korištene su robusne standardne pogreške.

Tablica 1. Rezultati procijenjenih modela

\begin{tabular}{|c|c|c|c|c|}
\hline Varijabla & $\begin{array}{c}\text { Združeni OLS } \\
\text { model }\end{array}$ & FE model & RE model & $\begin{array}{c}\text { Dinamički } \\
\text { panel }\end{array}$ \\
\hline GDP & $\begin{array}{c}16,7674 * \\
(0,000) \\
\end{array}$ & $\begin{array}{c}-4,7989 * \\
(0,0019)\end{array}$ & $\begin{array}{c}0,8944 \\
(0,4835)\end{array}$ & $\begin{array}{c}20,293^{*} \\
(0,000)\end{array}$ \\
\hline INFL & $\begin{array}{l}0,0011 \\
(0,977) \\
\end{array}$ & $\begin{array}{c}0,0309 \\
(0,1566) \\
\end{array}$ & $\begin{array}{l}-0,0156 \\
(0,3847) \\
\end{array}$ & $\begin{array}{l}-0,09 * \\
(0,002)\end{array}$ \\
\hline EXP & $\begin{array}{c}-0,6479 * \\
(0,000) \\
\end{array}$ & $\begin{array}{c}0,0012 \\
(0,9956) \\
\end{array}$ & $\begin{array}{l}-0,0292 \\
(0,8747) \\
\end{array}$ & $\begin{array}{l}-1,312^{*} \\
(0,000) \\
\end{array}$ \\
\hline EDU & $\begin{array}{l}-54,92^{*} \\
(0,000) \\
\end{array}$ & $\begin{array}{c}2,9365 \\
(0,6656) \\
\end{array}$ & $\begin{array}{l}-4,6222 \\
(0,4204) \\
\end{array}$ & $\begin{array}{c}-57,619^{*} \\
(0,000) \\
\end{array}$ \\
\hline URBAN & $\begin{array}{l}0,0677 * \\
(0,0044)\end{array}$ & $\begin{array}{l}-0,1942 \\
(0,1328) \\
\end{array}$ & $\begin{array}{c}0,0632 \\
(0,2786) \\
\end{array}$ & $\begin{array}{c}0,7407^{*} \\
(0,000) \\
\end{array}$ \\
\hline YOUNG & $\begin{array}{l}-0,1115^{*} \\
(0,0074) \\
\end{array}$ & $\begin{array}{c}0,0577 \\
(0,4936)\end{array}$ & $\begin{array}{l}-0,0428 \\
(0,5142)\end{array}$ & $\begin{array}{c}-0,3049 * * \\
(0,019)\end{array}$ \\
\hline KRIZA & $\begin{array}{c}-1,5768^{* *} \\
(0,0134) \\
\end{array}$ & $\begin{array}{l}0,0019 \\
(0,994) \\
\end{array}$ & $\begin{array}{c}-0,061 \\
(0,8038) \\
\end{array}$ & $\begin{array}{l}-0,1906 \\
(0,603) \\
\end{array}$ \\
\hline $\begin{array}{l}\text { Pomak zavisne } \\
\text { varijable }\end{array}$ & - & 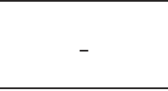 & . & $\begin{array}{c}0,0883^{* *} \\
(0,0308) \\
\end{array}$ \\
\hline \multicolumn{5}{|l|}{ Dijagnostika } \\
\hline $\mathrm{N}$ & 378 & 378 & 378 & 338 \\
\hline F-test/Waldov test & & $87,92^{*}$ & & $4268,77^{*}$ \\
\hline $\begin{array}{l}\text { Breusch-Paganov } \\
\text { LM test }\end{array}$ & & & $1236,952^{*}$ & \\
\hline Hausmanov test & & & $59,5^{*}$ & \\
\hline
\end{tabular}

Napomena: modeli uključuju i konstantni član, koji nije prikazan u ispisu.

U zagradama su naznačene $p$-vrijednosti.

$*, * * \mathrm{i} * * *$ označava da je varijabla statistički signifikantna na razini $1 \%, 5 \%$ odnosno $10 \%$.

Heterogenost analiziranih zemalja OECD-a potvrđena je i provođenjem statističkih testova koji ukazuju na postojanje individualnih učinaka, odnosno na neprikladnost združenog OLS modela. Među procijenjenim statičkim panel modelima, Hausmanov test ukazao je na panel model s fiksnim učincima kao prikladan odabir. Međutim, u RE modelu nije značajna niti jedna varijabla, dok je u FE modelu značajna samo varijabla dohodak.

Budući da je velik broj odnosa u ekonomiji dinamičke prirode, procijenjen je i dinamički panel model. Pomak zavisne varijable statistički je značajan, što ukazuje na prikladnost dinamičkog panel modela. Nadalje, vrijednost parametra uz pomak zavisne varijable blizu je nule, što ukazuje na relativno brzo otklanjanje neravnoteže i da je model dinamički stabilan. 
U pogledu predznaka procijenjenih parametara, dohodak i urbanizacija imaju pozitivan učinak na potražnju za životnim osiguranjem zemalja OECD-a. S druge strane, inflacija, obrazovanje, očekivani životni vijek i omjer zavisnosti mladih imaju negativan učinak na potražnju za životnim osiguranjem u zemljama OECD-a.

Sukladno očekivanju, porast standarda (mjereno kao porast dohotka po stanovniku) dovodi do povećanja potražnje za životnim osiguranjem u zemljama OECD-a, što je u skladu s rezultatima prethodnih istraživanja poput Beck i Webb (2003), Outreville (1996), Li et al. (2007) i Beenstock et al. (1986), koji utvrđuju da je dohodak najznačajniji ekonomski čimbenik odrednica potražnje za životnim osiguranjem.

Urbanizacija, odnosno porast udjela gradskog u ukupnom stanovništvu dovodi do povećanja potražnje za životnim osiguranjem zemalja OECD-a, kao i u radu Beck i Webb (2003). Također, sukladno očekivanju, inflacija kao indikator povećane neizvjesnosti vodi ka smanjenju potražnje za životnim osiguranjem kao oblikom dugoročnog ulaganja. Takav rezultat potvrđuje zaključke prethodnih istraživanja (Outreville, 1996; Ward i Zurbruegg, 2002; Canh et al., 2020). Nadalje, empirijska analiza pokazala je da se s povećanjem očekivanog životnog vijeka očekuje smanjenje potražnje za životnim osiguranjem zemalja OECD-a, što je u skladu s literaturom (Li et al, 2007).

Omjer zavisnosti mladih ima negativan učinak na potražnju za životnim osiguranjem zemalja OECD-a, što je u suprotnosti s rezultatima istraživanja Beenstock et al. (1986), Browne i Kim (1993) te Truett i Truett (1990), koji ukazuju na pozitivan učinak omjera zavisnosti mladih na potražnju za životnim osiguranjem, dok Beck i Webb (2003) u svom istraživanju zaključuju da je omjer zavisnosti mladih u dvosmislenoj korelaciji sa životnim osiguranjem.

Obrazovanje ima negativan učinak na potražnju za životnim osiguranjem zemalja OECD-a, iako se u literaturi općenito smatra da bi viši stupanj obrazovanja trebao imati pozitivan učinak na potražnju za životnim osiguranjem zemalja OECD-a (Truett i Truett, 1990; Outreville, 1996; Li et al., 2007).

Moguće objašnjenje negativnog utjecaja demografskih varijabli jest u sve izraženijem utjecaju starenja stanovništva, koje rezultira znatnim smanjenjem relativnog udjela radnog kontingenta u ukupnom stanovništvu, odnosno onog dijela stanovništva koji čine najveći udio kupaca polica životnog osiguranja.

U skladu s očekivanjem i dugoročnim karakterom životnog osiguranja, globalna ekonomska i financijska kriza 2008. godine nema statistički značajan učinak na potražnju za životnim osiguranjem zemalja OECD-a. Međutim, premda sama varijabla kriza nema statistički značajan učinak na potražnju za životnim osiguranjem zemalja OECD-a, vrlo je vjerojatno da je određenim djelom utjecala na odrednice potražnje za životnim osiguranjem zemalja OECD-a.

\section{ZAKLJUČAK}

Sukladno sve većoj važnosti životnih osiguranja, članak istražuje odrednice potražnje za životnim osiguranjem zemalja OECD-a u razdoblju od 2008. do 2018. godine. Pritom su, kao moguće odrednice, analizirani različiti ekonomski, demografski i socijalni čimbenici. 
Očekivano, rezultati provedenih testova ukazali su da združeni OLS model nije prikladan te je u empirijskoj analizi korišten dinamički panel model. Pritom, primijenjen je Arellano-Bover / Blundell-Bond sistemski procjenitelj koji se smatra prikladnijim kada broj analiziranih razdoblja nije velik.

Iz provedenog istraživanja na uzorku zemalja OECD-a u vrlo specifičnom razdoblju između 2008. i 2018. godine, koje je obilježeno globalnom financijskom krizom te post-kriznim razdobljem, razvidno je da dohodak i urbanizacija imaju pozitivan učinak na potražnju za životnim osiguranjem zemalja OECD-a te da s druge strane, inflacija, obrazovanje, očekivani životni vijek i omjer zavisnosti mladih imaju negativan učinak na potražnju za životnim osiguranjem zemalja OECD-a.

Učinci dohotka, urbanizacije, inflacije te životnog vijeka na potražnju za životnim osiguranjem u zemljama OECD-a u skladu su s rezultatima prethodnih istraživanja, dok su učinci omjera zavisnosti mladih i obrazovanja na potražnju za životnim osiguranjem u zemljama OECD-a u suprotnosti s prethodnim istraživanjima. Moguće objašnjenje negativnog utjecaja demografskih varijabli jest u sve izraženijem utjecaju starenja stanovništva, koje rezultira znatnim smanjenjem relativnog udjela radnog kontingenta u ukupnom stanovništvu, odnosno onog dijela stanovništva, koji čini najveći udio kupaca polica životnog osiguranja. Nadalje, u skladu s očekivanjem i dugoročnim karakterom životnog osiguranja, globalna ekonomska i financijska kriza 2008. godine nema statistički značajan učinak na potražnju za životnim osiguranjem zemalja OECD-a.

Cilj svake empirijske analize jest, osim što omogućuje bolje sagledavanje prošle dinamike varijabli, omogućiti pogled unaprijed. Pogled unaprijed polazi od mogućnosti predviđanja kretanja analiziranih varijabli u budućnosti, najčešće na temelju opažanja prošle dinamike i određenih očekivanja. U ovom slučaju, pogled unaprijed je u znatnoj mjeri otežan uslijed aktualne koronakrize i nemogućnosti sagledavanja svih mogućih posljedica kao i samog trajanja krize. Šok izazvan pandemijom bolesti COVID-19, koja je započela početkom 2020. godine, dakle izvan analiziranog razdoblja, a utječe na svjetsku ekonomiju, posebno na strukturu financijskih tržišta uključujući i životna osiguranja, premda predstavlja ograničavajući faktor za predikciju buduće dinamike potražnje za životnim osiguranjem zemalja OECD-a, otvara prostor za nova istraživanja na temu potražnje za životnim osiguranjima te predstavlja izazov istraživačima i u narednom razdoblju.

\section{POPIS LITERATURE}

1. Alvarez, J., Arellano, M. (2003). The time series and cross-section asymptotics of dynamic panel data estimators. Econometrica, 71(4), str. 1121-1159.

2. Anđelinović, M., Mišević, P., Pavković, A. (2016). Determinante potražnje za životnim osiguranjem u novim zemljama članicama Europske unije: analiza panel podataka. Notitia-časopis za održivi razvoj, 2, str: 1-12.

3. Baltagi, B. H. (2013). Econometric Analysis of Panel Data. 5th ed. Chichester, UK: Wiley.

4. Arellano, M., Bover, O. (1995). Another look at the instrumental variable estimation of error-components models.Journal of Econometrics, 68, str. 29-51. 
5. Beck, T.,Webb, I. (2003). Economic, Demographic and Institutional Determinants of Life Insurance Consumption across Countries. The World Bank Economic Review, 17 (1), str: 51-88.

6. Beenstock, M., Dickinson, G., Khajuria, S. (1986). The Determinants of Life Premiums: An International Cross-Section Analysis 1970-1981. Insurance: Mathematics and Economics,5 (4), str. 261-270.

7. Blackburne III, E. F., Frank, M. W. (2007). Estimation of nonstationary heterogeneous panels. The Stata Journal, 7(2), str. 197-208.

8. Blundell,R. W., Bond, S. (1998). Initial conditions and moment restrictions in dynamic panel data models.Journal of Econometrics, 87, str. 115-143.

9. Browne, M. J., Kim, K. (1993). An International Analysis of Life Insurance Demand. Journal of Risk and Insurance,60(4), str. 616-634.

10. Canh, N. P., Wongchoti, U., Thanh, S. D. (2020). Does economic policy uncertainty matter for insurance development? Evidence from 16 OECD countries. The Geneva Papers on Risk and Insurance-Issues and Practice, str. 1-35.

11. Ćurak, M., Kljaković-Gašpić, M. (2011). Economic and social determinants of life insurance consumption-evidence from central and eastern Europe. The Journal of American Academy of Business, 16(2), str. 216-222.

12. Ćurak, M., Kovač, D., Pepur, S. (2019). Informiranost korisnika financijskih usluga i potražnja za životnim osiguranjem. ,Svjetski financijski vrtlog - 30 godina poslije“ Znanstveni skup povodom 10. godišnjice smrti akademika Ive Perišina.

13. Elango, B., Jones, J. (2011). Drivers of insurance demand in emerging markets. Journal of Service Science Research, 3(2), str. 185-204.

14. Hakansson, N. H. (1969). Optimal Investment and Consumption Strategies under Risk, and under Uncertain Lifetime and Insurance. International Economic Review, 10, str. 443-466.

15. Human Development Reports, Data [online]. Dostupno na: https://bit.ly/3iDZC7t [Pristupljeno: 01. 05. 2020.]

16. Hwang, T., Gao, S. (2003). The determinants of the demand for life insurance in an emerging economy-the case of China. Managerial Finance, 29(5/6), str. 82-96.

17. Jakšić, S., Erjavec, N., Čeh Časni, A. (2020). Metode primijenjene matematičke i statističke analize. Zagreb: Ekonomski fakultet Zagreb.

18. Kjosevski, J. (2012). The Determinants of Life Insurance Demand In Central and Southeastern Europe. International Journal of Economics and Finance, 4(3), str. 237-247.

19. Li, D., Moshirian, F., Nguyen, P., Wee, T. (2007). The Demand for Life Insurance in OECD Countries. The Journal of Risk and Insurance,74(3), str. 637-652.

20. OECD, Stat. [online] Dostupno na: https://bit.ly/2BtCrN1 [Pristupljeno 23. 06. 2020.]

21. OECD (2004). Developing life insurance in the economies in transition. OECD Secretariat. [online] Dostupno na: http://www.oecd.org/pensions/insurance/1857819.pdf [Pristupljeno 04. 02. 2021.]

22. Outreville, J. F. (1996). Life Insurance Markets in Developing Countries. Journal of Risk and Insurance, 63(2), str. 263-278. 
23. Truett, D. B.,Truett, L. J. (1990). The demand for life insurancein Mexico and the United States: A comparative study. Journal of Risk and Insurance, 57(2), str.321-328.

24. Ward, D., Zurbruegg, R. (2000). Does Insurance Promote Economic Growth? Evidence from OECD Countries. Journal of Risk and Insurance, 67(4), str. 489-506.

25. World Bank, Data [online]. Dostupno na: https://bit.ly/3knoTmM [Pristupljeno: 01. 05. 2020.]

26. Yaari, M. E. (1965). Uncertain Lifetime, Life Insurance, and the Theory of the Consumer.Review of Economic Studies, 32, str. 137-150.

27. Zerriaa, M., Noubbigh, H. (2016). Determinants of Life Insurance Demand in the MENA Region. The Geneva Papers on Risk and Insurance - Issues and Practice,41 (3), str. 491-511. 